\title{
Anthropometric Deficit in Normative Minimum Spaces for Housing in Mexico
}

\author{
J. G. Lorenzo-Palomera ${ }^{1}$, Y. G. Aranda-Jimenez ${ }^{1}$, K. Suarez-Dominguez ${ }^{2, *}$, L. A. Brandt-Garcia ${ }^{2}$ \\ ${ }^{1}$ Faculty of Architecture, Design and Urbanism, The Autonomous University of Tamaulipas, South University Centre, Universidad \\ Poniente, 89109, Tampico, Tamaulipas, Mexico \\ ${ }^{2}$ Research Center, FADU, Autonomous University of Tamaulipas, South University Centre, Universidad Poniente, 89109, Tampico, \\ Tamaulipas, Mexico
}

Received July 11, 2021; Revised August 9, 2021; Accepted September 21, 2021

\section{Cite This Paper in the following Citation Styles}

(a): [1] J. G. Lorenzo-Palomera, Y. G. Aranda-Jimenez, K. Suarez-Dominguez, L. A. Brandt-Garcia , "Anthropometric Deficit in Normative Minimum Spaces for Housing In Mexico," Civil Engineering and Architecture, Vol. 9, No. 6, pp. 1869-1876, 2021. DOI: 10.13189/cea.2021.090619.

(b): J. G. Lorenzo-Palomera, Y. G. Aranda-Jimenez, K. Suarez-Dominguez, L. A. Brandt-Garcia (2021). Anthropometric Deficit in Normative Minimum Spaces for Housing In Mexico. Civil Engineering and Architecture, 9(6), 1869-1876. DOI: 10.13189/cea.2021.090619.

Copyright@2021 by authors, all rights reserved. Authors agree that this article remains permanently open access under the terms of the Creative Commons Attribution License 4.0 International License

Abstract The dimensions of houses in accordance with housing law, rules and regulations in Mexico are established based on standards without a precise basis in anthropometric requirements. Therefore, equal house prototypes are built in different regions of the country, although the physical characteristics of people are dissimilar. Education and strategies in architect formation require adapted information for house design. Given this scenario, the study's objective is to contrast such metric standardization with the volume of personal space delimited by body segments of population samples in three regions of Mexico. For this, an anthropometric database was generated, considering body mass, height, reach, body mass index, and personal space. Data are integrated concerning minimum dimensions of areas established in the minimum housing regulations, and necessary furniture measures are incorporated. Measurements were sorted by a given number of cases from each city. Similarities and differences between anthropometric data in the samples of three cities and the information that must be considered in the architectonic design were shown. When comparing minimum normative dimensions with anthropometric data and necessary furniture measurements, some volumetric discrepancies are evident. The Housing Law requires humanization, focusing on the inhabitants, their requirements and characteristics as added values of adequate housing. This paper is a new way to introduce the parametric analysis and consideration in Mexico and a basis for laws development.

Keywords Normative Space, Minimum Housing Anthropometry

\section{Introduction}

Suppose all manufactured attire is minimized with metric standards related to summerise clothing for whoever wears it to adapt to body characteristics of the human population. What about houses and its institutions [1]. What about housing and institutionalized dimensions as a minimum?

Standardization is a specialized technical activity that allows companies to access international markets, contributing to the reduction of production costs, facilitating the advancement in technology [2,3]. Standardization creates norms that establish the common characteristics that the products must meet.

Standardization consists of adjusting someone or something to a type or pattern; manufacture a product in series according to a certain standard or standard [4]. Synonym of typifying and homogenizing reduces the number or variety of items to be produced to fit them to a type or model. A standard refers to the most common or 
current or meets the characteristics common to the majority. However, in the case of design, such as architecture, dedicated to shaping living space, people do not have similar characteristics, rather the variability in their features is constant. Even so, the average dimensional profile is mostly used in determining minimum measures for housing. It is incorrect for design solutions to be developed based on average people's measurements [5], the workplace, for instance, considers the range of measurements of the human body to ensure their effectiveness. Due to the complexity of certain design problems involving varied body dimensions, there is not a sufficient trend in body dimensions, which can be associated with different population size groups [6].

From the technical point of view, the average is a theoretical data obtained from the division of the sum of all the data in a sample, among the total data; that is, it is not a real data, and the real data that by chance are the same are few [7]. This data, average or arithmetic mean, only indicates that all the others are grouped around it, and never that most of the data is equal to it. It was used since ancient time for edification [8].

\section{Literature Review instead of Minimum Space Regulation}

The regulatory framework related to housing is implemented for its operation in provisions categorized at national, State and municipal levels, and in constitutional and legislative orders.

The housing regulations in Mexico are based on article 4 of the Political Constitution of the United Mexican States, which establishes the rights of people, among which is the enjoyment of decent and dignified housing. The Law will establish the necessary instruments and supports in order to achieve that objective.

In the Housing Law (2019) [9] it is established in Article 2:

Decent and dignified housing will be considered to be the one that complies with the applicable legal provisions in matters of human settlements and construction, health, has habitable and auxiliary spaces, as well as with basic services and provides its occupants with legal security regarding their property or legitimate possession, and contemplates criteria for disaster prevention and physical protection of its occupants against potentially aggressive natural elements.

Based on this Law, housing policy has, as its central axis, the fulfilment of the State's obligations related to promoting, respecting, protecting, and guaranteeing the right of the Mexican population to adequate housing.

The power to regulate the constructions is stipulated in article 115 of the Constitution of the United Mexican States, establishing that, according to the terms of federal and state laws, the municipalities are empowered to grant building licenses and permits, as regards which can issue the necessary regulations and administrative provisions.

The municipalities generally regulate: (a) the constructions (including those of housing) with regulation of municipal construction and with complementary technical norms to this; and (b) the construction of the urban complex (including housing complexes) with plans, programs, regulations and guidelines for urban development.

Because the regulations in the country have great differences, both in their content and in their scope, CONAVI - based on Article 72 of the Housing Law - and within the framework of the National Housing Program 2019-2024 (SEDATU, 2019 [10]), formulated the Housing Building Code (CEV) so that the competent authorities of each locality can apply and keep up to date: (a) legal provisions; (b) standards; (c) codes; and (d) construction regulations. The CEV can also be used as a design tool for architects and engineers to make better construction and design decisions, thus offering better habitability conditions (CONAVI, 2017).

Other documents are the Construction Regulations of Mexico City (2018), Technical Standards for Architectural Design (2011: 18). Likewise, the Institute of the National Housing Fund for Workers INFONAVIT (2006), gathers minimum dimensions for spaces based on regulations of different entities. In such documents, two-dimensional data are established that limit surfaces, that is, buildable square meters per room in a dwelling.

On the other hand, some municipalities establish their own regulatory guidelines, either based on federal regulations, or local circumstances.

In any case, in Mexico, the measures established in the institutional housing regulations create minimums without foundation in the variable population metric. If they were based on furniture, it would be necessary to consider dimensions of the interaction of people with such objects.

Human beings are entities whose space requirement is three-dimensional. The body is a reference of measure and distance in the process of adaptation in interaction with objects and surroundings. This minimal interface can be set with personal space.

\section{Conceptual Framework}

There are no two users that have the same shape or size, which causes a significant obstacle for designers trying to achieve a universally accepted product. Variability in human size, shape, strength, and other characteristics have a high impact on the ability of users to interact with designs. A user is accommodated if all the user's physical variables conform to those limits [11], in addition to considering anthropometric changes that occur in people during the day [12]. 
In activities of daily living, such as food or precision tasks in a workstation, they fall mainly in the region near the torso [13]. As for space for maintenance activities, a minimum functional level it can make the person uncomfortable due to the narrow space. On the other hand, an optimal operational level of the area is wide enough so that a maintenance task can be performed comfortably [14]. Personal space is delimited by an invisible border surrounding a person's body, which intruders cannot cross [15]. Such distance varies in a dynamic fluctuation according to emotions and mental State [16, 17]; including the effect caused by music [18].

Different perceptions of distance, depending on the cultural factors of the subjects, are [15]:

- Intimate distance in its distant phase, from 15 to 45 centimeters.

- Personal distance, in its two phases, from 45 to 120 centimeters.

- Social distance, between 120 and 360 centimeters.

- Public distance, more than 360 centimeters.

The range of spatial extension from the body encompasses pericutaneous, peripersonal, extrapersonal, and interpersonal variants [17]. The peripersonal space represents the area around the body where objects are coded in for the purpose of voluntary actions aimed at objectives, there is a link with the interpersonal comfort space by sharing a universal motor nature [19]. The relationship among reach distances has been found in such areas based on emotional states of anxiety and comfort [20].

The peripersonal space changes its amplitude due to a secure link between visual and tactile perception, especially when a visual stimulus approaches the body, causing a prediction of the likely consequences of contact [21]. It also responds to collaborative social interaction [22] and uncomfortable as listening to conversations with aggressive content [23]. In the activity, the workspace is considered as accessible when it can be generated empirically, adjusting a spherical surface to the experimental data [24], or by kinematic models that represent the upper limb as a manipulator, where the maximum attainable distance, away from the torso, decreases as the hand load increases [25, 26]. Reach is an essential component of functional activities since the arms are used from 8 to $9 \mathrm{~h}$ per day [27]. In addition, it is known that height and weight are the ones that most contribute to the variation of body shape [28], along with age.

In the user-space interaction, the body referent determines the distance relationships to carry out activities. The body space, with its volume, its perceptual boundaries and reach, dimensionally refers to the person in his or her habitat. The interface where the basic interactions of living are carried out is the personal, three-dimensional space, where experiences related to movement in an area are given.

The extended arm's reach, forward, upward and sideways defines the envelope of the activity space, that is, the frontal, vertical and lateral ranges [29]. It is a slack factor to provide space for the head, elbow, legs, for adequate access and movement. Zones of convenient reach, zones of optimal vision, zones of regular activity are established.

For example, in kitchen space, the location of wall cabinets requires analyzing heights and dimensions to ensure that persons of legal age access comfortably [30]. The combination of furniture heights and height of inhabitants can cause risk of musculoskeletal injuries [31].

When the space is accessible, in its range, there are objects with which it can interact immediately. It specifies a private area in social interactions and contains the obstacles to which the organism must pay attention to avoid colliding with them by gesturing or moving the body, the construction material characteristic can intervene in this [32].

In this work, two personal space details are defined and used: the own total space, calculating the volume generated by the distance of the lateral reach extending both arms horizontally, squared (area), multiplied by the height of vertical reach. On the other hand, the frontal personal space $(\mathrm{Esp}<$ ), volume obtained from the product of arm reach extended to the front, by the lateral reach, and multiplied by the distance of the vertical reach. A colorful and non-spherical volume was defined as personal space because the housing spaces are regularly quadrangular.

The study contrasts the dimensions of the space established by federal regulations, with the volume derived from body segments of population samples from three cities in Mexico.

\section{Methodology}

In this case, cities located in the northeast (ZMT Tampico Metropolitan Zone, Tamaulipas) were considered; northwest (Tijuana, Baja California), and southwest (Оахаса, Оахаса).

A table was made with measures established as a minimum, obtained from regulations, based on Federal regulations (NF): CONAVI, 2017; PAOT, 2018; Secretariat of Works and Services of the Federal District Government, 2011, and municipal regulations: SINFRA, 1998 for Oaxaca (NO); Tamaulipas State Congress, 2012 for Tampico (NTa); and H Tijuana City Council, 2015 for Tijuana (NTi). See table 1. 
Table 1. Table 1 measures established as a minimum, obtained from regulations, based on Federal regulations

\begin{tabular}{|c|c|c|c|c|c|c|c|c|c|c|c|c|c|c|c|c|}
\hline \multirow[b]{2}{*}{$\begin{array}{l}\text { INHABITED } \\
\text { SPACE }\end{array}$} & \multicolumn{4}{|c|}{ Side (1m) } & \multicolumn{4}{|c|}{ Area $\left(\mathrm{m}^{2}\right)$} & \multicolumn{4}{|c|}{ Height (1m) } & \multicolumn{4}{|c|}{ Volumen $\left(\mathrm{m}^{3}\right)$} \\
\hline & & NO & NTa & NTi & & NO & NTa & NTi & & NO & NTa & NTi & & NO & NTa & $\mathrm{NTi}$ \\
\hline Main bedroom & 2.40 & 2.50 & 2.40 & 3.00 & 7.00 & 7.50 & 7.00 & 9.00 & 2.30 & 2.50 & 2.30 & 2.30 & 16.10 & 18.75 & 16.10 & 20.70 \\
\hline $\begin{array}{l}\text { Additional } \\
\text { bedroom }\end{array}$ & 2.20 & 2.50 & 2.20 & 3.00 & 6.00 & 7.50 & 6.00 & 9.00 & 2.30 & 2.50 & 2.30 & 2.30 & 13.80 & 18.75 & 13.80 & 20.70 \\
\hline Bedchamber & 2.00 & 2.50 & 2.20 & 1.70 & 3.60 & 7.50 & 6.00 & 4.59 & 2.30 & 2.50 & 2.30 & 2.30 & 8.28 & 18.75 & 13.80 & 10.55 \\
\hline Living room & 2.60 & 2.50 & 2.60 & 3.00 & 7.30 & 7.50 & 7.30 & 9.00 & 2.30 & 2.50 & 2.30 & 2.30 & 16.79 & 18.75 & 16.79 & 20.70 \\
\hline Dining room & 2.40 & 2.50 & 2.40 & 3.00 & 6.30 & 7.50 & 6.30 & 9.00 & 2.40 & 2.50 & 2.30 & 2.30 & 14.49 & 18.75 & 14.49 & 20.70 \\
\hline $\begin{array}{l}\text { MERGED } \\
\text { SPACE }\end{array}$ & & NO & NTa & $\mathrm{NTi}$ & & NO & NTa & NTi & & NO & NTa & $\mathrm{NTi}$ & & NO & NTa & $\mathrm{NTi}$ \\
\hline $\begin{array}{l}\text { Living room } \\
\text { Dining room }\end{array}$ & 2.40 & 2.50 & 2.60 & 3.00 & 12.00 & 7.50 & 13.00 & 15.90 & 2.70 & 2.50 & 2.30 & 2.30 & 32.40 & 18.75 & 29.90 & 36.57 \\
\hline $\begin{array}{l}\text { Living room } \\
\text { Kitchen- } \\
\text { Dining room } \\
\end{array}$ & 2.40 & 2.50 & 2.40 & 3.00 & 14.60 & 7.50 & 14.60 & 19.80 & 2.70 & 2.50 & 2.70 & 2.30 & 39.40 & 18.75 & 39.40 & 45.54 \\
\hline $\begin{array}{l}\text { Single inhabited } \\
\text { space }\end{array}$ & 2.60 & 2.50 & 2.60 & 3.00 & 25.00 & 7.50 & 25.00 & 25.00 & 2.30 & 2.50 & 2.30 & 2.30 & 57.50 & 18.75 & 57.50 & 57.5 \\
\hline Service space & & NO & $\mathrm{NTa}$ & $\mathrm{NTi}$ & & NO & NTa & NTi & & NO & $\mathrm{NTa}$ & NTi & & NO & $\mathrm{NTa}$ & $\mathrm{NTi}$ \\
\hline Kitchen & 1.50 & 1.50 & 1.50 & 1.50 & 3.00 & 3.00 & 3.00 & 3.75 & 2.30 & 2.30 & 2.30 & 2.30 & 6.90 & 6.90 & 6.90 & 8.62 \\
\hline Laundry room & 1.40 & 1.40 & 1.40 & 1.60 & 1.68 & 1.68 & 1.68 & 2.88 & 2.10 & 2.10 & 2.10 & 2.30 & 3.53 & 3.53 & 3.53 & 6.62 \\
\hline Bathroom & 1.30 & 1.30 & 1.40 & 1.10 & 2.73 & 2.73 & 2.73 & 2.53 & 2.10 & 2.10 & 2.10 & 2.30 & 5.73 & 5.73 & 5.73 & 5.82 \\
\hline $\begin{array}{l}\text { Quadrangular half } \\
\text { bath }\end{array}$ & 1.30 & 1.30 & 1.40 & 1.10 & 1.69 & 1.69 & 1.69 & 1.54 & 2.10 & 2.10 & 2.10 & 2.30 & 3.55 & 3.55 & 3.55 & 3.54 \\
\hline $\begin{array}{l}\text { Rectangular half } \\
\text { bath }\end{array}$ & 0.80 & 0.80 & 0.80 & 0.80 & 1.44 & 1.44 & 1.44 & 1.44 & 2.10 & 2.10 & 2.10 & 2.30 & 3.02 & 3.02 & 3.02 & 3.31 \\
\hline
\end{tabular}

Source: Mexican Federal Regulations, 2020 


\subsection{Sample}

The sample was not probabilistic, at convenience. Formed by people from the cities of Oaxaca $\left(17^{\circ} 05^{\prime} 00^{\prime \prime} \mathrm{N}\right.$ $96^{\circ} 45^{\prime} 00^{\prime \prime} \mathrm{O}, 1555$ masl), Tampico (22 $15^{\circ} 19^{\prime \prime} \mathrm{N} 97^{\circ} 52^{\prime}$ $07^{\prime \prime} \mathrm{W}, 30$ masl) and Tijuana ( $32^{\circ} 31^{\prime} 51^{\prime \prime} \mathrm{N} 117^{\circ} 01^{\prime} 12^{\prime \prime}$ $\mathrm{W}, 20$ masl). Chosen by the possibility of having voluntary subjects to carry out measurements, during stays, in addition to being located in regions with different geographical characteristics and populations. See Table 2.

Table 2. Sample general data

\begin{tabular}{|c|c|c|c|c|c|}
\hline & & Oaxaca & Tijuana & ZMT & TOTAL \\
\hline \multirow{2}{*}{$\mathrm{n}$} & & 52 & 57 & 70 & 179 \\
\hline \multirow{3}{*}{ Age } & Min & 14 & 14 & 17 & 14 \\
\cline { 2 - 6 } & Max & 61 & 91 & 50 & 91 \\
\cline { 2 - 6 } & Mean & 27.76 & 36.29 & 22.50 & 28.42 \\
\cline { 2 - 6 } & $\mathrm{s}$ & 13.05 & 16.94 & 5.92 & 13.72 \\
\hline \multirow{3}{*}{ Gender } & $\mathrm{F}$ & 22 & 32 & 30 & 84 \\
\cline { 2 - 7 } & $\mathrm{M}$ & 30 & 25 & 40 & 95 \\
\hline
\end{tabular}

Source: INEGI, 2018.

Measurements of body segments were carried out in each city: height (E), weight (P), vertical reach (AV), lateral reach (AL), frontal reach (AF. The tools used were Smartmet aluminum stadiometer to measure height, Smartmet segmometer to measure reaches, and Beurer GS28 glass scale to measure weight, the Body Mass index with the weight and height ratio was obtained, data arrangements were made from smallest to largest, and normalized.

Volumetric dimensions of space around the person, derived from body segments, were checked against the volumes generated by the measures established in regulations for minimum housing spaces in Mexico.

\section{Data Analyses and Discussion}

The measurements were sorted by a sample from each city and integrated into a single database. The standardized data are presented in Table 3 and Table 4: the minor data $(<\mathrm{d})$, the major data $(>\mathrm{d})$, the mean $(\mathrm{m})$, and the standard deviation (s) for each variable.

Table 3 shows similarities and differences between anthropometric data in the samples of three cities. The mean (m) in variables such as height and reach is almost the same in the samples, even though they are populations in different regions of the country, however, the average in weight, BMI, maximum personal space (ESP) and frontal personal space $($ Esp $<$ ) differs. The difference between minor data $(\mathrm{d}<$ ) and major data of each variable evidences population metric variability in terms of total personal space, observing ESP Oaxaca, $3.53 \mathrm{~m}^{3}$; ESP Tijuana, $6.50 \mathrm{~m}^{3}$; ESP Tampico, $4.16 \mathrm{~m}^{3}$. As for front personal space, Esp < Oaxaca, $2.23 \mathrm{~m}^{3}$; Esp $<$ Tijuana, 2.73 $\mathrm{m}^{3}$; Esp <Tampico, $2.09 \mathrm{~m}^{3}$.

By grouping the sample data in the three cities, variable ranges can be seen considering quartile 1 and quartile 3 . See table 4.

Table 3. Anthropometric data by samples of each city

\begin{tabular}{|c|c|c|c|c|c|c|c|c|c|c|c|c|c|}
\hline & \multicolumn{4}{|c|}{ OAXACA $\mathrm{n}=52$} & \multicolumn{4}{c|}{ TIJUANA $\mathrm{n}=57$} & \multicolumn{5}{c|}{ TAMPICO=70 } \\
\hline & $<\mathrm{d}$ & $>\mathrm{d}$ & $\mathrm{m}$ & $\mathrm{s}$ & $<\mathrm{d}$ & $>\mathrm{d}$ & $\mathrm{m}$ & $\mathrm{s}$ & $<\mathrm{d}$ & $>\mathrm{d}$ & $\mathrm{m}$ & $\mathrm{s}$ \\
\hline Weight & 47 & 98 & 66.43 & 14.06 & 45 & 123 & 71.83 & 14.34 & 42 & 93 & 63.01 & 12.17 \\
\hline Stat & 1.48 & 1.86 & 1.62 & 0.10 & 1.49 & 1.98 & 1.64 & 0.10 & 1.47 & 1.88 & 1.64 & 0.08 \\
\hline $\mathrm{IMC}$ & 18.38 & 35.38 & 23.03 & 3.70 & 16.53 & 42.56 & 25.56 & 4.48 & 16.14 & 36.79 & 22.93 & 3.91 \\
\hline $\mathrm{AL}$ & 1.47 & 1.89 & 1.65 & 0.11 & 1.39 & 2.05 & 1.64 & 0.13 & 1.46 & 1.89 & 1.67 & 0.11 \\
\hline $\mathrm{AF}$ & 0.65 & 0.93 & 0.78 & 0.07 & 0.66 & 0.98 & 0.81 & 0.06 & 0.70 & 0.98 & 0.81 & 0.05 \\
\hline $\mathrm{AV}$ & 1.80 & 2.37 & 2.05 & 0.14 & 1.64 & 2.51 & 2.05 & 0.15 & 1.76 & 2.31 & 2.06 & 0.14 \\
\hline $\mathrm{ESP}$ & 5.33 & 8.86 & 6.84 & 1.00 & 3.17 & 9.67 & 5.79 & 1.35 & 3.90 & 8.06 & 5.83 & 1.17 \\
\hline Esp $<$ & 1.89 & 4.12 & 2.72 & 0.92 & 1.89 & 4.62 & 3.12 & 0.83 & 1.83 & 3.92 & 2.73 & 0.67 \\
\hline
\end{tabular}

Source: Own elaboration

Table 4. Data from the total sample

\begin{tabular}{|c|c|c|c|c|c|c|}
\hline & $<\mathrm{d}$ & $>\mathrm{d}$ & $\mathrm{m}$ & $\mathrm{s}$ & $\mathrm{Q} 1$ & $\mathrm{Q} 3$ \\
\hline Weight & 42 & 123 & 66.89 & 13.66 & 55.00 & 76.60 \\
\hline Stat & 1.47 & 1.98 & 1.64 & 0.09 & 1.59 & 1.72 \\
\hline IMC & 16.14 & 42.56 & 24.09 & 4.12 & 21.36 & 26.34 \\
\hline AL & 1.39 & 2.05 & 1.65 & 0.11 & 1.58 & 1.76 \\
\hline AF & 0.65 & 0.98 & 0.80 & 0.06 & 0.77 & 0.86 \\
\hline AV & 1.64 & 2.51 & 2.06 & 0.14 & 1.96 & 2.17 \\
\hline ESP & 3.17 & 9.67 & 5.79 & 1.23 & 4.91 & 6.70 \\
\hline Esp< & 1.83 & 4.62 & 2.78 & 0.68 & 2.39 & 3.23 \\
\hline
\end{tabular}

Source: Own elaboration 
Table 5. Grouping of personal space and volume of basic furniture

\begin{tabular}{|c|c|c|c|c|c|c|c|c|c|c|c|}
\hline \multirow[t]{2}{*}{ Space } & \multirow{2}{*}{$\begin{array}{c}\text { Furniture } \\
\text { volume } \mathrm{m}^{3}\end{array}$} & \multirow{2}{*}{$\begin{array}{c}\begin{array}{c}\text { ESP } \\
\mathrm{m}^{3}\end{array} \\
\text { Q3 }\end{array}$} & \multirow{2}{*}{$\begin{array}{c}\text { Esp< } \\
\text { Q3 }\end{array}$} & \multicolumn{2}{|c|}{ Unipersonal Home } & \multicolumn{2}{|c|}{ Four-people home } & \multirow{2}{*}{$\begin{array}{l}\mathrm{NF} \\
\mathrm{m}^{3}\end{array}$} & \multirow{2}{*}{$\begin{array}{l}\mathrm{NO} \\
\mathrm{m}^{3}\end{array}$} & \multirow{2}{*}{$\begin{array}{c}\text { NTa } \\
\mathrm{m}^{3}\end{array}$} & \multirow{2}{*}{ NTi ${ }^{3}$} \\
\hline & & & & $\mathrm{ESP}^{3}$ & Esp $<$ & $\mathrm{ESP}^{3}$ & Esp $<$ & & & & \\
\hline Living Room & 2.324 & 6.7 & 3.23 & 9.024 & 5.554 & 29.124 & 15.244 & 16.79 & 18.75 & 16.79 & 20.7 \\
\hline Dining Room & 1.123 & 6.7 & 3.23 & 7.823 & 4.353 & 27.923 & 14.043 & 14.49 & 18.75 & 14.49 & 20.7 \\
\hline $\begin{array}{c}\text { Master } \\
\text { Bedroom }\end{array}$ & 1.282 & 6.7 & 3.23 & 7.982 & 4.512 & 14.682 & 7.742 & 16.1 & 18.75 & 16.1 & 20.7 \\
\hline $\begin{array}{c}\text { Additional } \\
\text { bedroom }\end{array}$ & 1.562 & 6.7 & 3.23 & 8.262 & 4.792 & 14.962 & 8.022 & 13.8 & 18.75 & 13.8 & 20.7 \\
\hline Kitchen & 1.054 & 6.7 & 3.23 & 7.754 & 4.284 & 7.754 & 4.284 & 6.90 & 6.90 & 6.90 & 8.62 \\
\hline Bathroom & 2.773 & 6.7 & 3.23 & 9.473 & 6.003 & 9.473 & 6.003 & 5.73 & 5.73 & 5.73 & 5.82 \\
\hline $1 / 2$ bathroom & 0.726 & 6.7 & 3.23 & 7.426 & 3.956 & 7.426 & 3.956 & 3.55 & 3.55 & 3.55 & 3.54 \\
\hline Laundry & 1.207 & 6.7 & 3.23 & 7.907 & 4.437 & 7.907 & 4.437 & 3.53 & 3.53 & 3.53 & 6.62 \\
\hline VOLUME $\mathrm{m}^{3}$ & 12.051 & & & 65.651 & 37.891 & 119.251 & 63.731 & 80.89 & 94.71 & 80.89 & 107.4 \\
\hline SURFACE $\mathrm{m}^{2}$ & & & & & & 51.85 & 27.71 & 35.17 & 41.18 & 35.17 & 46.70 \\
\hline
\end{tabular}

Source: Own elaboration

Table 6. Spaces and basic furniture

\begin{tabular}{|c|c|c|c|c|c|c|c|}
\hline $\begin{array}{l}\text { Living } \\
\text { Room }\end{array}$ & $\begin{array}{l}\text { Dining } \\
\text { Room }\end{array}$ & $\begin{array}{c}\text { Master } \\
\text { Bedroom }\end{array}$ & $\begin{array}{l}\text { Additional } \\
\text { Bedroom }\end{array}$ & Kitchen & Bathroom & $1 / 2$ bathroom & Laundry \\
\hline $\begin{array}{c}\text { Couch } \\
\text { Sofa 2p } \\
\text { Sofa 3p } \\
\text { Coffee } \\
\text { table }\end{array}$ & $\begin{array}{c}\text { Table } \\
\text { 4 Chairs }\end{array}$ & $\begin{array}{l}\text { Double bed } \\
2 \text { bureaus }\end{array}$ & $\begin{array}{c}\text { Indiv beds(2) } \\
\text { Bureau (2) }\end{array}$ & $\begin{array}{c}\text { Refrigerator } \\
\text { Sink } \\
\text { Stove }\end{array}$ & $\begin{array}{c}\text { Shower } \\
\text { Toilet } \\
\text { Sink }\end{array}$ & $\begin{array}{l}\text { Toilet } \\
\text { Sink }\end{array}$ & $\begin{array}{c}\text { Washing } \\
\text { machine } \\
\text { Drying } \\
\text { machine } \\
\text { Buddle }\end{array}$ \\
\hline
\end{tabular}

Source: Furniture volumetry adapted from Steegman and Acebillo, 2008.

Table 5 shows an example considering the ESP and Esp $<$, from quartile Q3, adding basic furniture volumetry for each space (table 6). What is stipulated in regulations is exceeded, mainly in cases of auxiliary service spaces. Although the significant limitations are contrasted with federal regulations (NF), in the case of the city of Tijuana (NTi), there are more space provisions.

In the lower rows, the sum of volume by space was calculated, and it was converted to the surface by dividing by 2.30 . No circulation measures were added within areas or between spaces. It is also understood that the dynamics of personal space include overlays or intersections in an interface where several people interact with each other, with objects in a room; or when space is regularly used by a person, such as a bathroom. But differences appear between volumes destined for households of four members with the minimum regulatory spaces.

Table 6 spaces and basic furniture. Furniture volumetry adapted from Steegman and Acebillo, 2008 [33].

The insufficiency of minimum space from the regulations, the difference in size between the inhabitants and the metric specifications for housing makes necessary an extension of the minimum space envelope.

Human variability implies a diversity of specific requirements. Gender, age, occupation, nutrition, among other factors, characterize people. This is not reflected in the housing prototype, since, although different sizes of houses can be found, when reviewing their dimensions in an anthropometric sense, they are not adequate.

There is a gap in the current regulations since their dimensional proposals do not correspond to each other, which facilitates various interpretations because the differences are not entirely concise or justified; the area allocated in the housing regulations fluctuates from $18.75 \mathrm{~m} 2$ to $57.23 \mathrm{~m} 2$ [34]. The volume of this range of surfaces is not enough for the accommodation of the group of inhabitants that can make up the variety of households in the country.

\section{Recommendation and Conclusions}

A The study sample covers a relatively small percentage of people; however, the population of three different regions of the country illustrates the problem of the minimum size of housing, originated in a dimensional deficit of spaces raised in regulations, given the anthropometric characterization based on the spatial volume of people generated by reach distance. That is, different people require different areas and adequate to the volumetric requirements.

The volume data obtained in the study (see table 5) reflect a discrepancy between anthropometric measures and dimensions established in regulations since the 
standards in rules are not based on the physical characteristics of the population, but on representative human scales of average measures.

Volumes were managed for single-person and nuclear homes made up of up to four people; however, in Mexico, households with a higher number of members can coexist, as well as with different complexions. This widens the gap between space requirements associated with the number of family group members, their dimensional characteristics, and metric standards of housing size. That is, there is a discrepancy between the space requirements for the type of homes and the minimum dimensions stipulated in regulations.

The data contrast design criteria based on averages, because the size of housing decreases based on production costs, but the dynamics of body configuration derives from multiple variables. This implies considerations of space in terms of activities, movements, routes, interaction with equipment and furniture.

A substantial effect is the intervention of housing due to situations such as overcrowding and limited dimensions, with repercussions on the family economy due to extra expenses and impact on the environment due to demolition waste.

The use of personal space as a reference is an important contribution since the three-dimensionality of the inhabitants requires regulatory provisions according to human nature. Therefore, the units should use cubic meters in addition to square and linear meters, to determine the minimum living space in housing.

Just as the variability was demonstrated in terms of personal space, its components in reach, clearance, height, weight, also show differences. This suggests new housing studies with an anthropometric approach, where the regulations are based on the dimensional variability of the inhabitants. Although personal space was considered as a metric reference, new studies can relate such volume with effects on psychological and emotional states in housing inhabitants in the interaction between users, objects and environment.

\section{Acknowledgements}

YGAJ thanks to UAT-2021 Project. KSD and LABG thanks to the project CONACYT 2021.

\section{REFERENCES}

[1] De Rubeis, V., Bayat, S., Griffith, L. E., Smith, B. T., \& Anderson, L. N. "Validity of self - reported recall of anthropometric measures in early life: A systematic review and meta - analysis”. Obesity Reviews, Vol. 20 No. 10, pp. 1426-1440. 2019. https://doi.org/10.1111/obr.12881.
[2] Gejdoš, M., \& Lipoldová, M. "Drivers Workplace of Transport Vehicles in Relation to Anthropometric Dimensions of Adult Population in Slovakia”. Transportation Research Procedia, Vol. 44, 321-326, 2020. https://doi.org/10.1016/j.trpro.2020.02.036

[3] Kim, H. S., Choi, H. E., Park, C. K., \& Nam, Y. J. "Standardization of the size and shape of virtual human body for apparel products”. Fashion and Textiles, Vol. 6 No. 1, pp. 33, 2019. https://doi.org/10.1186/s40691-019-0187-z

[4] RAE. "Estandarizar. Diccionario de la lengua española” 2019 From: https://dle.rae.es/

[5] Hertzberg, H.T.E. “Average Man Is a Fiction: Range of Sizes Is Key to Efficient Work Places”. Contract, pp. 86-89. septiembre, 1970.

[6] Haslegrave, C. M. "Characterizing the anthropometric extremes of the population” Ergonomics, 29:2, 281-301. 1986. https://doi.org/10.1080/00140138608968265

[7] Ávila Ch., R.; Prado L., L. R.; González M., E. L. "Dimensiones antropométricas de la población latinoamericana: México, Cuba, Colombia, Chile” México. Centro Universitario de Arte, Arquitectura y Diseño. Centro de Investigaciones en Ergonomía. Universidad de Guadalajara. 2007.

[8] Valle-Chavarria, L. G., Berumen-Rodriguez, C. E., \& Suarez-Dominguez, E. J. "A Study of the Formal Architectural-Sculptural Characteristics of El Tajin”. Conservation Science in Cultural Heritage, Vol. 19. No.1, pp. 143-156, 2019.

https://doi.org/10.6092/issn.1973-9494/9992

[9] H. Congreso de la Unión. Cámara de Diputados "Housing Laws”. General Department, Mexican Goverment. Secretaría de Servicios Parlamentarios Última Reforma DOF 14-05-2019. 2019, www.diputados.gob.mx.

[10] Secretaria de Desarrollo Agrario, Territorial y Urbano SEDATU. Programa Nacional de Vivienda 2019-2024. Gobierno de México. Desarrollo Territorial. 2019 https://www.gob.mx/cms/uploads/attachment/file/513323/ Programa_Nacional_de_Vivienda_2019-2024.pdf

[11] Ferguson, T.; Greene, M.; Repetti, F.; Lewis, K.; Behdad, S. "Combining anthropometric data and consumer review content to inform design for human variability". Proceedings of the ASME 2015 International Design Engineering Technical Conferences \& Computers and Information in Engineering Conference. IDETC/CIE, 2019.

[12] Bragança, S.; Arezes, P.; Carvalho, M.; Ashdown, S. P.; Leão, C. "Assessment of the intraday variability of anthropometric measurements in the work environment: a pilot study”. International journal of occupational safety and ergonomics. 2017. DOI: 10.1080/10803548.2017.1322803

[13] Castro, M. N, Rasmussen, J., Bai, S, Andersen, M. S. “The reachable 3-D workspace volume is a measure of payload and bodymass-index: A quasi-static kinetic assessment”. Applied Ergonomimcs Vol. 75, 108-119, 2019.

[14] Guo Z, Zhou D, Liu P, He Z, Lv C “A quantitative assessment method for the space design of products based on ergonomics and virtual simulation”. PLoS ONE Vol. 13 No. 7: e0200880, 2018. 
https://doi.org/10.1371/journal.pone.0200880

[15] Hall, Edward T. “La dimensión oculta”. México. Siglo XXI editores. 2003.

[16] Low, S.M.-D.Lawrence_Zúñiga. The anthropology of space and place. Locating culture. USA. Blackwell Publishing Ltd. 2003.

[17] Bourgeois, J.; Alessandro Farnè, A.; Yann Coello, Y. "Costs and benefits of tool-use on the perception of reachable space”. Acta Psychologica Vol. 148, pp. 91-95. 2014. http://dx.doi.org/10.1016/j.actpsy.2014.01.008

[18] Tajadura-Jiménez A, Pantelidou G, Rebacz P, Västfjäll D, Tsakiris M. "I-Space: The Effects of Emotional Valence and Source of Music on Interpersonal Distance" PLoS ONE 6(10): e26083. 2008 https://doi.org/10.1371/journal.pone.0026083

[19] Quesque, F.; Ruggiero, G.; S. Mouta, S.; J. Santos, J.; Iachini, T.; Coello, Y. Keeping you at arm's length: modifying peripersonal space influences interpersonal distance. Psychological Research. Vo. 81, pp.709-720, 2017. DOI 10.1007/s00426-016-0782-1

[20] Iachini, T.; Ruggiero, G.; Ruotolo, F.; Schiano di Cola, A.; Senese, V.P. "The influence of anxiety and personality factors on comfort and reachability space: a correlational study”. Cogen Process, Vol. 16 (Suppl 1): S255-S258. 2015. DOI 10.1007/s10339-015-0717-6

[21] de Haan, A. M.; Smit, M.; Van der Stigchel, S.: Dijkerman, H. C. "Approaching threat modulates visuotactile interactions in peripersonal space”. Exp Brain Res Vol. 234, pp.1875-1884, 2016. DOI 10.1007/s00221-016-4571-2

[22] Coello Y, Quesque F, Gigliotti M-F, Ott L, Bruyelle J-L "Idiosyncratic representation of peripersonal space depends on the success of one's own motor actions, ibut also the successful actions of others!” PLoS ONE Vol. 13, No. 5, e0196874, 2018. https://doi.org/10.1371/journal.pone.0196874

[23] Vagnoni E, Lewis J, Tajadura-JimeÂnez A, Cardini F. "Listening to a conversation with aggressive content expands the interpersonal space”. PLoS ONE 13(3): e0192753, 2018. https://doi.org/10.1371/journal.pone.0192753

[24] Kurillo, G., Han, J.J., Obdržálek, Š., Yan, P., Abresch, R.T., Nicorici, A., Bajcsy, R. "Upper extremity reachable workspace evaluation with Kinect”. In: Medicine Meets
Virtual Reality, pp. 247-253. 2013.

[25] Matthew, R.P., Kurillo, G., Han, J.J., Bajcsy, R. Calculating reachable workspace volume for use in quantitative medicine. In: Agapito, L., Bronstein, M.M., Rother, C. (Eds.), ECCV 2014 Workshops, Part III, Lecture Notes in Computer Science. Springer International Publishing, Cham, pp. 570-583. 2015.

[26] Johnston, H., Dewis, C., Kozey, J. "Effect of hand-held loads on the maximum reach envelope”. Occup. Ergon. 12, 179-187. 2015.

[27] Bailey RR, Lang CE. "Upper-limb activity in adults: referent values using accelerometry”. J Rehabil Res Dev; Vol. 50 No. 9 pp. 1213-22, 2013

[28] Cottle, F. S. "Statistical Human Body Form Classification: Methodology Development and Application”. (Graduate Faculty of Auburn University. Doctor of Philosophy Dissertation 2012). ProQuest LLC.

[29] Pheasant, S. y Haslegrave, C. M. "Bodyspace Anthropometry, Ergonomics and the Design of Work". 2018 Third Edition. Philadelphia. Taylor \& Francis e-Library. CRC Press.

[30] Hrovatin, J.; Silvana Prekrat, S.; Leon Oblak, L.; and David Ravnik, D. "Ergonomic Suitability of Kitchen Furniture Regarding Height Accessibility”. Coll. Antropol. Vol. 39 No. 1: 185-191, 2015.

[31] Sharma SM, Shaikh FV, Bhovad PD, Kale JS, Gupta YP, Bhuta MB. "Risk of musculoskeletal disorders associated with kitchen platform tasks in young and middle-aged women of a metropolitan city: An observational cross-sectional study”. Indian J Occup Ther; Vol. 51 pp. 130-5, 2019.

[32] Suárez-Domínguez, E. J., Aranda-Jiménez, Y. G., Palacio-Pérez, A., Rodríguez-Valdés, A., \& Izquierdo-Kulich, E. "Oscillating temperature profile model for a poured earth wall”. Concreto y cemento. Investigación y desarrollo, Vol. 7 No.1, 44-51, 2015.

[33] Steegman, E. - J. Acebillo. Las medidas en arquitectura. Barcelona. Editorial Gustavo Gili. 2008.

[34] Martínez R., A. de J.; Díaz N., V.L. "Vivienda mínima, revisión conceptual y dimensional de la normatividad aplicable en México.Vivienda y Comunidades Sustentables”. Año 2, núm. 4, julio-diciembre de 2018/ 